\title{
Determining Multivariate Analysis Sampling Frequency for Monitoring Contamination Caused by Trout Farms
}

\author{
Mitra Tavakol', Reza Arjmandi ${ }^{2 *}$, Mansoureh Shayeghi ${ }^{3}$, \\ Seyed Masoud Monavari ${ }^{2}$, Abdolreza Karbassi ${ }^{4}$ \\ ${ }^{1}$ Department of Environmental Science, Faculty of Environment and Energy, \\ Science and Research Branch, Islamic Azad University, Tehran, Iran \\ ${ }^{2}$ Department of Environmental Science, Faculty of Environment and Energy, \\ Science and Research Branch, Islamic Azad University, Tehran, Iran \\ ${ }^{3}$ Department of Medical Entomology and Vector Control, School of Public Health, \\ Tehran University, Tehran, Iran \\ ${ }^{4}$ Department of Environmental Engineering, School of Environment, \\ Tehran University, Tehran, Iran
}

Received: 4 April 2016

Accepted: 26 July 2016

\begin{abstract}
Recent rapid growth of the aquaculture industry and the necessity to comply with environmental standards suggest the need for studies on the possible negative effects of this type of industry. One of the most devastating effects of aquaculture is water pollution caused by the discharge of untreated effluent from fish farms into aquatic ecosystems. Assessment of the pollutants requires an optimal design of a water monitoring network in a way to demonstrate changes in aquatic environments. Accordingly, the present study used multivariate statistical analysis to determine sampling frequency for optimal monitoring of the contaminants resulting from trout farms in the Haraz River in northern Iran. For this purpose, a total number of 17 physical and chemical water quality parameters were sampled monthly over a one-year period based on the instructions recommended in the standard method (2005) [1]. The results showed that changes in biochemical oxygen demand (BOD) during the warm months of summer were very high and reached its peak in August and September. This may be attributed to the increased fish production in fish farms, increased food intake to feed the fish, and higher rate of discharge from fish farms containing waste feed and fish faeces. The nitrate also reached its maximum level in June due to the same reasons. Conversely, dissolved oxygen (DO) level was the lowest in the warm months (August and September). The reason would be increased consumption of DO due to higher production rate in the fish farms and increased metabolism of fish in warm months. Overall, the findings confirmed the applicability of multivariate techniques in
\end{abstract}

*e-mail: Rezarjmandi@gmail.com 
determining temporal frequency of the measurements during the monitoring period. By which it would be possible to recognize the reality of changes in water quality, with fewer measurements, and in less time and cost.

Keywords: aquatic, environment, monitoring, quality, fish farm

\section{Introduction}

Surface water resources have a great potential for contamination. They have long been threatened seriously by human and industrial activities. Wastewater from manufacturing and non-manufacturing industries can jeopardize the ecological equilibrium of aquatic habitats [2-5]. One of the most common uses of water resources is aquaculture, and cold-water fish farms along rivers have become a common sight.

The wastewater from these sites is directly discharged into rivers and causes many adverse effects, such as disruption of the natural equilibrium in aquatic ecosystems [6-10]. The development of aquaculture and the necessity to comply with environmental standards clarify the need to study the potential adverse effects of this industry. One of the most devastating effects of aquaculture is microbial contamination of the receiving aquatic environments and outbreaks of parasitic diseases among aquatics, which are usually caused by the discharge of untreated effluent from fish farms into aquatic ecosystems [11-14].

Nowadays, aquaculture activities, as one of the most important sources of food supply in the world, have enjoyed high rates of growth. In line with the development of aquaculture, like any other industry, its resulting environmental effects have become the center of attention worldwide. As such, Pine and Boyd (2011) examined the effect of fish farms on salinization of surface water resources in the Blackland Prairie region [15]. They confirmed damaging effects of the industry on the aquatic environment and reported that the chloride contents exceeded the in-stream standard of $230 \mathrm{mg} / \mathrm{L}$ for chloride concentration in freshwater, as recommended by the Alabama Department of Environmental Management. Saremi et al. (2013) studied the effects of aquaculture effluent on water quality parameters of the Haraz River [16]. According to their report, construction of highcapacity fish farms can have a significant impact on the Haraz Basin, especially by reducing dissolved oxygen (DO) and increasing the concentration of nutrients and biochemical oxygen demand (BOD). In another study by Mohseni Bandpei and Yousefi (2013) on the Haraz River, the status of water quality parameters was checked along the river. According to their results, a significant difference was observed between the levels of total phosphate in upstream and downstream areas of the fish farms [17].

Ruiz-Zarzuela et al. (2009) studied the effects of fish farming on the water quality of 12 rivers in northeastern Spain [18]. Their results showed a significant decrease in $\mathrm{pH}$ and $\mathrm{DO}$, as well as a sharp increase in chemical oxygen demand (COD), ammonium, phosphates, and microbial parameters downstream of the fish farms.
Varedi et al. (2009) studied the effect of effluent from rainbow trout fish farms on Haraz River water quality and reported that the levels of electrical conductivity (EC), total dissolved solids (TDS), ammonium $\left(\mathrm{NH}_{4}^{+}\right)$, nitrite $\left(\mathrm{NO}_{2}\right)$, total phosphorous (TP), and phosphate ions $\left(\mathrm{PO}_{4}^{-3}\right)$ were significantly different from one farm to another [19].

Mahboobi Soofiani et al. (2012) investigated the effects of effluent from the trout fish farms on the water quality of the Zayanderood River in Iran [20]. Although the concentration of none of the water quality parameters exceeded the permissible limits, levels of BOD, COD, and TSS showed a significant increase surrounding the fish farms.

As observed, fish farms can be a source of contamination for aquatic environments. This clarifies the need for quality control of receiving environments. Due to the high cost of water quality analyses, determining the frequency of sampling is considered one of the most fundamental aspects of monitoring. Limiting the number of measurements in a way that the monitoring system, as a whole, can demonstrate the temporal changes of water quality parameters will lead to considerable savings in time and budget. Unfortunately, at present - despite the scarcity of drinking water in most cities and towns in Iran - there is no particular standard for establishing cold-water fish farms on permanent rivers. The fragility of surface water resources necessitates monitoring the pollutants at the outlet of the fish farms and observing a safe distance between the nearby fish farms to allow self-purification of rivers. During recent years and in line with the policy in Iran to increase the production rate of fish, construction of cold-water fish farms along the Haraz has increased considerably. Unfortunately, most of them have been constructed without respecting environmental criteria and considerations. As such, most of the farms have been constructed adjacent to each other, without observing the necessary intervals between the upstream and downstream fish farms. Furthermore, the effluent from the fish farms is not treated before being discharged to the river.

Obviously, contamination of water resources by aquaculture activities will be a serious problem in the not too distant future, particularly due to the need for new sources to supply drinking water needs of the increasing population [6]. According to FAO in 2004, aquaculture activities along the Haraz supply more than one third of the fish consumed in the region [17].

The foregoing reveals the necessity for the measurement of pollutants from aquaculture industries. In this regard, this research was conducted to determine temporal sampling frequency of pollutants caused by Haraz trout farms in order to prepare an optimal environmental monitoring program. It should be 
mentioned that the Haraz is important for three reasons. First, it is the only permanent river passing through Amol, which gives special privileges to the urban landscape of that city. Second, the river is exposed to the contaminated effluent and wastewater from urban centers (Amol and Gazanak) and dozens of rural areas in the basin [21], its surroundings, and mineral hot springs. Third, the river is of great social importance for upstream areas in terms of drinking water supply for Amol through the Mangol Dam and, in the near future, to downstream areas due to water supply by a diversion dam.

According to the above-mentioned reasons, the present study was performed to monitor Haraz water quality as one of the most important water sources for drinking and agricultural purposes. The vulnerability of this water source, on the one hand, and high cost of water treatment and semi-humid weather conditions in the river basin, on the other hand, necessitates the control of contaminants at origin.

\section{Experimental Procedures}

\section{Study Area}

Haraz is one of the most important rivers in the Caspian Sea basin. It is also the largest river by discharge of water in western Mazandaran Province, and one of the three largest rivers by discharge of water in northern Iran
[22]. The river is $185 \mathrm{~km}$ in length [22] and the area of the river basin is approximately $5,100 \mathrm{~km}^{2}$, located in the northern part of Alborz Mountains within the latitudes $35^{\circ} 45^{\prime}-36^{\circ} 42^{\prime}$ E and longitudes $51^{\circ} 27^{\prime}-52^{\circ} 42^{\prime}$ E [23]. Figure 1 demonstrates a schema of the Haraz and the distribution pattern of the sampling points (the outlet of the fish farms).

\section{Research Procedure}

In this research, measurement parameters were prioritized based on a number of factors, including the polluting risk, public concern on a particular contaminant, controllability of the existing contamination sources and their potential for contamination, and the type of water use. The samples were taken monthly from 15 stations during a one-year period from September 2013 to September 2014. All of the 15 fish farms in the region were sampled. In general, our criteria for determining the sampling stations (based on proximity to fish farms) were:

1. Proximity to the inlet and outlet of fish ponds where a fish farm is located.

2. Before and after the discharge from point sources of pollution, fish ponds (where pollutants are mixed with water and a uniform state is created, as well as where there are several fish farms adjacent to each other).

In total, 17 parameters were tested in this research, including $\mathrm{BOD}, \mathrm{DO}$, nitrate, phosphate, TDS, ammonia
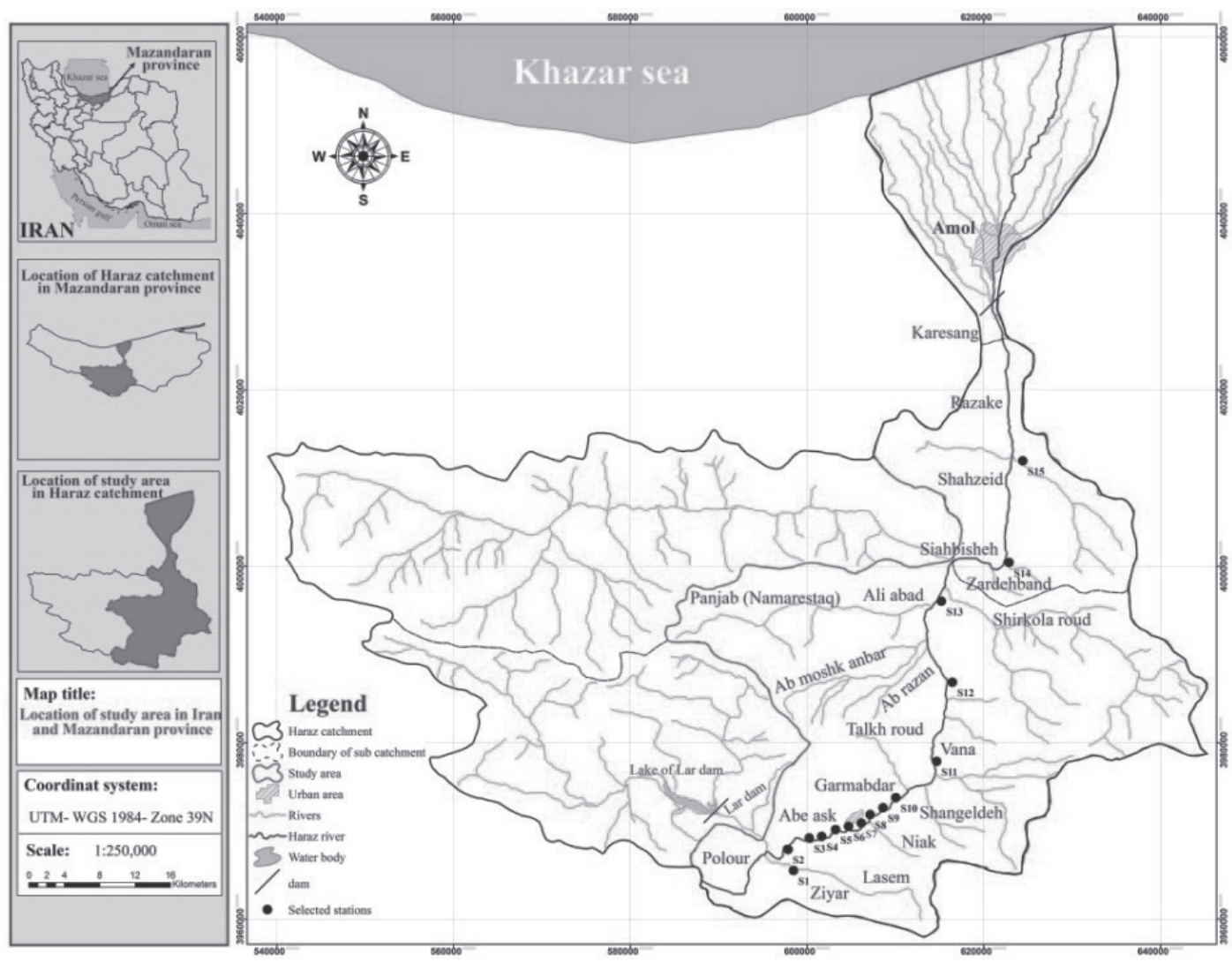

Fig. 1. The location of the Haraz River in Iran's Mazandaran Province. 
Table 1 . Water quality parameters, measurement units, and methods of analysis.

\begin{tabular}{|c|c|c|c|c|c|}
\hline No. & Parameter & Abbreviation & Unit & Laboratory standard & $\begin{array}{c}\text { Method or laboratory } \\
\text { device }\end{array}$ \\
\hline 1 & Electrical conductivity & $\mathrm{EC}$ & $\mu \mathrm{S} \mathrm{cm}^{-1}$ & Standard method & Sension156 Hach \\
\hline 2 & Dissolved oxygen & DO & $\mathrm{mgL}^{-1}$ & Standard method & Sension 156 Hach \\
\hline 3 & Turbidity & Turb. & NTU & Standard method & Sension 156 Hach \\
\hline 4 & Nitrate nitrogen & $\mathrm{No}_{3}^{-}$ & $\mathrm{mgL}^{-1}$ & Nitrate with Test & Spectrophotometric \\
\hline 5 & Ammonical nitrogen & $\mathrm{NH}_{3}$ & $\mathrm{mgL}^{-1}$ & Ammoniym with vario power pach & Spectrophotometric \\
\hline 6 & Phosphate & $\mathrm{PO}_{4}^{3-}$ & $\mathrm{mgL}^{-1}$ & Phosphate orth LR with Tube Test & Spectrophotometric \\
\hline 7 & $\begin{array}{l}\text { Biochemical oxygen } \\
\text { demand }\end{array}$ & BOD & $\mathrm{mgL}^{-1}$ & Instrumental method & Winkler azide method \\
\hline 8 & Total dissolved solids & TDS & $\mathrm{mgL}^{-1}$ & Standard method & Sension156 Hach \\
\hline 9 & Total suspended solids & TSS & $\mathrm{mgL}^{-1}$ & Standard method & Sension156 Hach \\
\hline 10 & Cadmium & $\mathrm{Cd}$ & $\mathrm{mgL}^{-1}$ & Cold evaporation method & Atomic Absorption \\
\hline 11 & Malathion & Malathion & $\mathrm{mgL}^{-1}$ & UV detector & HPLC \\
\hline 12 & Profenofos & Profenofos & $\mathrm{mgL}^{-1}$ & UV detector & HPLC \\
\hline 13 & Demethoat & Demethoat & $\mathrm{mgL}^{-1}$ & UV detector & HPLC \\
\hline 14 & Ethion & Ethion & $\mathrm{mgL}^{-1}$ & UV detector & HPLC \\
\hline 15 & Dichlorovous & Dichlorovous & $\mathrm{mgL}^{-1}$ & UV detector & HPLC \\
\hline 16 & Fenitrothion & Fenitrothion & $\mathrm{mgL}^{-1}$ & $\begin{array}{l}\text { NPD detector, } \mathrm{DOB}_{5} \text { column, and } \\
\text { nitrogen carrier gas }\end{array}$ & Gas chromatography \\
\hline 17 & Diazinon & Diazinon & $\mathrm{mgL}^{-1}$ & $\begin{array}{l}\text { NPD detector, } \mathrm{DOB}_{5} \text { column, and } \\
\text { nitrogen carrier gas }\end{array}$ & Gas chromatography \\
\hline
\end{tabular}

$\left(\mathrm{NH}_{3}\right)$, total suspended solids (TSS), turbidity, cadmium (Cd), EC, and seven toxins. Analysis of the samples was carried out according to the instructions provided in the Standard Method in 2005. [1]. Table 1 gives the measurement methods and devices used for sample analysis.

Before statistical analyses, the normality and proportionality of the experimental data was tested using the Kolmogorov-Smirnov (K-S) test. For this, the goodness of fit test for normal distribution was done using parametric methods. Data obtained from sampling and analyses over the one-year period were grouped and analyzed based on the fitting model.

The Kolmogorov-Smirnov test (KS-test) tries to determine if two datasets differ significantly. The KStest has the advantage of making no assumption about the distribution of data. (Technically speaking, it is nonparametric and distribution free.) Note, however, that this generality comes at some cost: other tests (for example Student's t-test) may be more sensitive if the data meet the requirements of the test.

The sampling frequency in water quality monitoring depends on several factors, including the objectives and significance of monitoring, pollution source type, qualitative indicator parameters, and available facilities. "Mean" is the most common statistical parameter for assessing water quality parameters. The main purpose of the determination of the sampling frequency is to provide a good estimation of mean. For this, it is required to first specify a "confidence interval around the mean" to recognize the relationship between sampling frequency and changes in water quality. A $100 \%$ confidence interval (1- $\alpha$ ) around the population mean is calculated as follows:

$$
\left[\bar{X}-Z_{a / 2} \bullet \operatorname{var}(\bar{X})^{0.5}, \bar{X}+Z_{a / 2} \bullet \operatorname{var}(\bar{X})^{0.5}\right]
$$

...where $\mathrm{Z}_{\mathrm{a} / 2}$ is the frequency coefficient of the standard normal distribution for the possibility of increasing $a / 2$. For example, for the confidence level of $95 \%, Z_{0.025}$ will be 1.96. If the samples are independent, then:

$$
\operatorname{Var}(\bar{X})=\frac{\sigma^{2}}{n}
$$

...where $\mathrm{n}$ is the number of samples and $\sigma$ is the variance of population.

Therefore, the 95\% confidence interval around the mean of population will be:

$$
\left[\bar{X}-1.96 \times \frac{\sigma}{\sqrt{n}}, \bar{X}+1.96 \times \frac{\sigma}{\sqrt{n}}\right]
$$


Table 2. Statistical specifications of water quality parameters (physiochemical variables and toxins).

\begin{tabular}{|c|c|c|c|c|c|}
\hline Parameter & unit & Minimum & Maximum & Mean & Std. Deviation \\
\hline DO & $\mathrm{mg} / \mathrm{L}$ & 3.50 & 9.10 & 6.2361 & 1.09037 \\
\hline BOD & $\mathrm{mg} / \mathrm{L}$ & 1.00 & 150.00 & 25.4278 & 36.25007 \\
\hline kodorat & NTU & 7.00 & 1490.00 & 310.2278 & 424.05799 \\
\hline nitrat & $\mathrm{mg} / \mathrm{L}$ & .04 & 8.10 & 2.4266 & 2.08437 \\
\hline phosphat & $\mathrm{mg} / \mathrm{L}$ & .01 & 3.70 & .7311 & .91388 \\
\hline TDS & $\mathrm{mg} / \mathrm{L}$ & 110.00 & $1,410.00$ & 493.9444 & 334.50692 \\
\hline $\mathrm{EC}$ & $\mathrm{mg} / \mathrm{L}$ & 200.00 & $1,320.00$ & 602.2667 & 234.13608 \\
\hline TSS & $\mathrm{mg} / \mathrm{L}$ & 25.00 & $1,890.00$ & 562.5389 & 502.40269 \\
\hline $\mathrm{NH}_{3}$ & $\mathrm{mg} / \mathrm{L}$ & .01 & .66 & .1246 & .13206 \\
\hline $\mathrm{Cd}$ & $\mu \mathrm{g} / \mathrm{L}$ & .0010 & .0900 & .022743 & .0231471 \\
\hline Diazinon & $\mathrm{mg} / \mathrm{L}$ & 1.35 & 3.21 & 2.4183 & .70675 \\
\hline Fenitrothion & $\mathrm{mg} / \mathrm{L}$ & .44 & .91 & .6750 & .18684 \\
\hline dichlorovous & $\mathrm{mg} / \mathrm{L}$ & .75 & 2.11 & 1.6167 & .51477 \\
\hline Ethion & $\mathrm{mg} / \mathrm{L}$ & .42 & .71 & .5683 & .11197 \\
\hline Demthout & $\mathrm{mg} / \mathrm{L}$ & .04 & .09 & .0617 & .01941 \\
\hline Profenofos & $\mathrm{mg} / \mathrm{L}$ & .35 & .62 & .4883 & .09867 \\
\hline Malathion & $\mathrm{mg} / \mathrm{L}$ & .90 & 2.50 & 1.5250 & .72360 \\
\hline
\end{tabular}

Narrow confidence intervals indicate a little uncertainty in the estimation of mean. In the above relation, variance $\left(\sigma^{2}\right)$ of the community is a part of its characteristics so that the network design cannot actually change it. The percentage of confidence level (1-a) should be selected based on the required accuracy and financial constraints.

In simple terms, the main objective in determining sampling frequency is to select " $n$ " in such a way to achieve, in accordance with the purposes of the monitoring network, acceptable widths for the confidence intervals around the population mean [24]. (Note that all statistical analyses and mathematical calculations were performed using Excel 2007, SPSS 16, and MINITAB 15 software.)

\section{Results and Discussion}

The results of the descriptive statistical tests, including central tendency and dispersion by the sampling data, are presented in Table 2. As shown, the highest and lowest DO levels were 9.1 and $3.5 \mathrm{ml} / \mathrm{L}$, respectively. For BOD, the highest measured level was $150 \mathrm{mg} / \mathrm{L}$. Furthermore, the highest and lowest levels of nitrate were 8.1 and $0.04 \mathrm{mg} / \mathrm{L}$, respectively, while the highest and lowest levels measured for phosphate were 3.7 and $0.01 \mathrm{mg} / \mathrm{L}$, respectively.

\section{Analysis of Water Quality in Different Months}

According to the statistical analysis of water quality parameters in different months, the lowest level of BOD was $1 \mathrm{mg} / \mathrm{L}$, observed in Stations 2 and 3, which is a sign of cleanness of the river water. In November, the lowest BOD level was $1 \mathrm{mg} / \mathrm{L}$, reported from Stations 1-4. This may attribute to the rapid flow of the river in the mountainous terrain of the region, which removed contaminants from the river water. The lowest Cd level in the same month was $0.001 \mu \mathrm{g} / \mathrm{L}$, reported from Stations 2-5. In December the lowest BOD was $1 \mathrm{mg} / \mathrm{L}$, observed in Stations 1-5. The low concentration of BOD in this month can be attributed to the cold weather conditions as well as the mountainous terrain of the region, which led the elimination of contaminants. The lowest level of phosphate in this month was $0.01 \mathrm{mg} / \mathrm{L}$, observed in Stations 3 and 4. Cold weather and mountainous terrain of the region were two factors behind the reduction of phosphate concentration in the region. The lowest $\mathrm{NH}_{3}$ level in this month was $0.01 \mathrm{mg} / \mathrm{L}$, reported from Station 15. Cold weather is the reason for the elimination of contamination in the region. The lowest $\mathrm{Cd}$ level in this month was $0.001 \mu \mathrm{g} / \mathrm{L}$ as reported from Stations 1-5.

In January, the highest turbidity level was 1,490 nephelometric turbidity units (NTU), measured in Station 
Table 3. ANOVA test results for the comparison of mean value of water quality parameters in different months of sampling.

\begin{tabular}{|c|c|c|c|c|c|c|}
\hline \multicolumn{2}{|c|}{ Parameter } & Sum of Squares & df & Mean Square & $\mathrm{F}$ & Sig. \\
\hline \multirow{3}{*}{ DO } & Between Groups & 123.066 & 11 & 11.188 & 20.942 & .000 \\
\hline & Within Groups & 89.749 & 168 & .534 & & \\
\hline & Total & 212.815 & 179 & & & \\
\hline \multirow{3}{*}{ BOD } & Between Groups & $127,340.594$ & 11 & $11,576.418$ & 18.028 & .000 \\
\hline & Within Groups & $107,877.467$ & 168 & 642.128 & & \\
\hline & Total & $235,218.061$ & 179 & & & \\
\hline \multirow{3}{*}{ nitrat } & Between Groups & 149.168 & 11 & 13.561 & 3.625 & .000 \\
\hline & Within Groups & 628.516 & 168 & 3.741 & & \\
\hline & Total & 777.685 & 179 & & & \\
\hline \multirow{3}{*}{ phosphat } & Between Groups & 65.688 & 11 & 5.972 & 11.971 & .000 \\
\hline & Within Groups & 83.808 & 168 & .499 & & \\
\hline & Total & 149.496 & 179 & & & \\
\hline \multirow{3}{*}{ TDS } & Between Groups & $2,812,179.178$ & 11 & $255,652.653$ & 2.495 & .006 \\
\hline & Within Groups & $17,217,004.267$ & 168 & $102,482.168$ & & \\
\hline & Total & $20,029,183.444$ & 179 & & & \\
\hline \multirow{3}{*}{$\mathrm{EC}$} & Between Groups & $1,722,534.533$ & 11 & $156,594.048$ & 3.252 & .000 \\
\hline & Within Groups & 8090192.667 & 168 & $48,155.909$ & & \\
\hline & Total & 9812727.200 & 179 & & & \\
\hline \multirow{3}{*}{ TSS } & Between Groups & 6333674.994 & 11 & $575,788.636$ & 2.490 & .006 \\
\hline & Within Groups & $38,847,439.733$ & 168 & $231,234.760$ & & \\
\hline & Total & $45,181,114.728$ & 179 & & & \\
\hline \multirow{3}{*}{ NH3 } & Between Groups & .337 & 8 & .042 & 3.120 & .006 \\
\hline & Within Groups & .675 & 50 & .013 & & \\
\hline & Total & 1.011 & 58 & & & \\
\hline \multirow{3}{*}{$\mathrm{Cd}$} & Between Groups & .021 & 11 & .002 & 4.419 & .000 \\
\hline & Within Groups & .071 & 161 & .000 & & \\
\hline & Total & .092 & 172 & & & \\
\hline
\end{tabular}

14. The high turbidity in this station may be related to the multiple sand and gravel workhouses in the region. The highest TDS level in January was $1,410 \mathrm{mg} / \mathrm{L}$, observed in Station 14 due to multiple sand and gravel workhouses in this region. The lowest cadmium level was $0.001 \mu \mathrm{g} / \mathrm{L}$ recorded in Stations 1, 4, 5, and 6. The lowest nitrate level was $0.04 \mathrm{mg} / \mathrm{L}$, measured in February at Station 2, which can be attributed to the cold weather and rapid flow of the river.

In March, the lowest $\mathrm{Cd}$ level was reported to be $0.001 \mu \mathrm{g} / \mathrm{L}$. The lowest Cd level in April was $0.001 \mu \mathrm{g} / \mathrm{L}$, measured in Stations 1-3. The lowest TSS level in May was $25 \mathrm{mg} / \mathrm{L}$, recorded in Station 1. The low amount of TSS can be attributed to the melting of snow at the Haraz headwaters and water purity. The lowest $\mathrm{Cd}$ level was $0.001 \mu \mathrm{g} / \mathrm{L}$, measured in Stations 1-2. The highest nitrate level in June was $8.10 \mathrm{mg} / \mathrm{L}$, as reported from Station 9 located in Garmabdar region, where there are several fish farms close to each other. The lowest TDS level in this month was $110 \mathrm{mg} / \mathrm{L}$, measured in Stations 3 and 4 upstream of the study area, where a high precipitation rate mitigates the contamination caused by TDS. The lowest $\mathrm{Cd}$ level in this month was $0.001 \mu \mathrm{g} / \mathrm{L}$ as recorded in Station 12, which could be due to the discharge of poison and remnant fertilizers containing heavy metals used by farmers.

The highest BOD in August was $150 \mathrm{mg} / \mathrm{L}$, reported from Station 10. This was mainly due to the close proximity of several fish farms and the warmth of the water, accelerating the rate of reactions. The highest phosphate level in this month was $3.7 \mathrm{mg} / \mathrm{L}$ as measured in Station 10, where there are several fish farms close each 
other and increased levels of minerals and nutrient content inside the pools. The highest TSS level in this month was $1,890 \mathrm{mg} / \mathrm{L}$ at Station 14, possibly due to the high levels of minerals released from sand and gravel warehouses and increased use of sand and gravel in this month. The highest $\mathrm{NH}_{3}$ level in this month was 0.66 at Station 13, which could be due to the proximity of the station to fish farms as well as the fish waste from the farms. The lowest $\mathrm{Cd}$ level in this month was $0.001 \mu \mathrm{g} / \mathrm{L}$ as reported from Stations 1-3. The highest $\mathrm{Cd}$ level in this month was $0.09 \mu \mathrm{g} / \mathrm{L}$ recorded from Stations 7 and 9, which could be due to the warm weather and overconsumption of chemical fertilizers as fish food. The lowest DO level in September was $3.50 \mathrm{mg} / \mathrm{L}$ as reported from Stations 13-14. The discharge of human wastewater at the site of sand and gravel workstations, and increased disposal of waste residuals from the fish farms into the river are the main reasons behind the decreased DO at this station. The highest EC level in this month was $1,320 \mathrm{mg} / \mathrm{L}$ measured at Station 15, which might be attributed to the discharge of human wastewater and waste residuals from fish farms into the river. The lowest $\mathrm{Cd}$ level in this month was 0.001 $\mu \mathrm{g} / \mathrm{L}$ as reported by Stations 1,4 , and 5 .

\section{Analysis of Variance and Comparison of the Mean Values}

\section{Statistical Test Results by Month}

To analyze the measurement data obtained from all 15 sampling stations, analysis of variance was conducted by SPSS in the form of fully randomized blocks. The analysis was done separately for sampling periods as replication and the sampling stations as treatment. The results of ANOVA test for the parameters measured in different periods indicated a significant difference between the sampling periods. Therefore, to ensure the test results of water quality parameters in different periods, the mean values were compared using the Duncan test at a 5\% level (Table 3).

Since, according to the ANOVA test, no significant difference was found between the mean values of turbidity in different months of sampling ( $\mathrm{p}$-value $\geq 0.05$ ), there was no need to use the Duncan post hoc-test for pairwise comparison of the turbidity parameter. For the rest of the measured parameters, a significant difference was observed in various months of sampling $(\mathrm{P} \leq 0.05)$. Therefore, Duncan was used to compare pair-wise the mean values of the measured parameters in different months. A brief description on the obtained results follows.

The lowest DO level was reported in September, possibly due to high oxygen demand in response to increased metabolism in the fish farms. The highest DO levels were observed in January, February, and March owing to the cold weather and elimination of contamination. A pair-wise comparison of BOD showed a significant difference in various months, at a confidence level of $95 \%$. The lowest BODs were observed in December, November, March, April, February, May,
January, and June, indicating decreased contamination and a reduction of BOD in fish farms at this time. The highest BODs were measured in August and September due to the warm weather and increased use of foodstuffs, together with the higher metabolism of fish in fish farms.

According to Duncan, we found that the nitrate levels significantly differed at the confidence interval of $95 \%$, within the various months of sampling. The lowest nitrate was measured in December, November, October, March, July, April, February, and August due to the discharge of fish farm effluent. The highest nitrate was reported in June, owing to consumption of foodstuffs and disposal of residuals from fish farms. A pair-wise comparison of phosphate levels by Duncan indicated that the parameter varied significantly, at the confidence interval of $95 \%$, over the different sampling months. The highest phosphate level was measured during September and August because of increased consumption of foodstuffs in fish farms and higher metabolism of fish in the warm months of the year. The lowest phosphate level was reported during December, November, October, March, February, January, April, and May due to the cold weather. Duncan revealed a significant difference of TDS (at a confidence interval of $95 \%$ ) in various months of sampling. The lowest TDS levels occurred in November, June, December, May, July, August, and September, which can be due to the cold weather and diminished water minerals. Based on the pair-wise comparison of EC levels by Duncan, it was observed that the parameter differed significantly in different months of sampling (confidence interval 95\%). The lowest EC values in December, June, May, November, March, April, and February were due to diminished water minerals in the cold months. The highest EC levels occurred in July, October, January, August, and September due to the increased levels of minerals in the water. A data comparison by Duncan indicated that there is a significant difference between the values of TSS in various sampling months at a confidence level of $95 \%$. TSS from the fish farms and sand and gravel workstations reached its peak in September, July, June, and August. On the contrary, in December, October, November, February, March, January, May, April, September, July, and June, TSS level was lower owing to the cold weather and reduced level of contamination.

The pair-wise comparison of Cd levels by Duncan revealed a significant difference in different months of sampling (confidence level 95\%). The highest levels of Cd were observed in September, July, and August owing to the use of chemical fertilizers containing heavy metals to feed the fish. The lowest $\mathrm{Cd}$ levels were recorded in June, April, May, March, December, November, October, and February.

Fig. 2 depicts the changing trends of nitrate, phosphate, DO, and BOD in different months of sampling. According to this figure, the BOD changes in the warm months of the year (in summer) were considerable and reached their peak in August and September. High levels of BOD in these months could be due to increased production 
in the fish farms, higher consumption of foodstuffs to feed the fish, and increased discharge from the fish farm containing fish fecal matter. Warm weather was also one of the causes for increased BOD at this time. As the temperature rises, the metabolism grows and this causes an increase in the demand for biological oxygen. The nitrate levels reached their maximum level in June, owing to increased consumption of foodstuffs to feed the fish as well as the increased discharge of effluent, containing fish fecal matter, from the fish farms due to the increased production during the month. In contrast, the DO level was the lowest in warm months of the year (August and September). The reason for the minimum level of DO in these months was increased demand for DO in the fish farms, resulting from higher production rates and increased metabolism during the warm months in fish farms. In research conducted in northwestern Poland, the greatest increase of organic matter and nutrients in a river was reported at the time of effluent discharge from fish farms when the $\mathrm{BOD}_{5}$ level increased from 8.9 to 18.3 $\mathrm{mgO} / \mathrm{dm}^{3}$ [25]. Farmaki et al. (2015) also highlighted the effect of aquaculture on increasing the level of phosphorus and nitrate in the receiving water resources [26]. LeónMuñoz et al. (2013) also investigated the concurrent effect of construction of trout farm pools and land use changes on the quality of water and sediments in Rupanco Lake in Chile and reported similar results [27]. León-Muñoz et al. (2013) revealed that nitrogen compounds increased dramatically either in water or sediments of the lake [27]. They attributed these changes to the conversion of the land use surrounding the lake to pastures, agricultural lands, and fish farms (Fig. 2).

The research findings showed that multivariate statistical analysis is very applicable in determining the sampling frequency in the sampling stations. The effectiveness of this method has been proven by many other studies with similar topics. As such, Lopes et al. (2014) used multivariate statistical methods to assess the

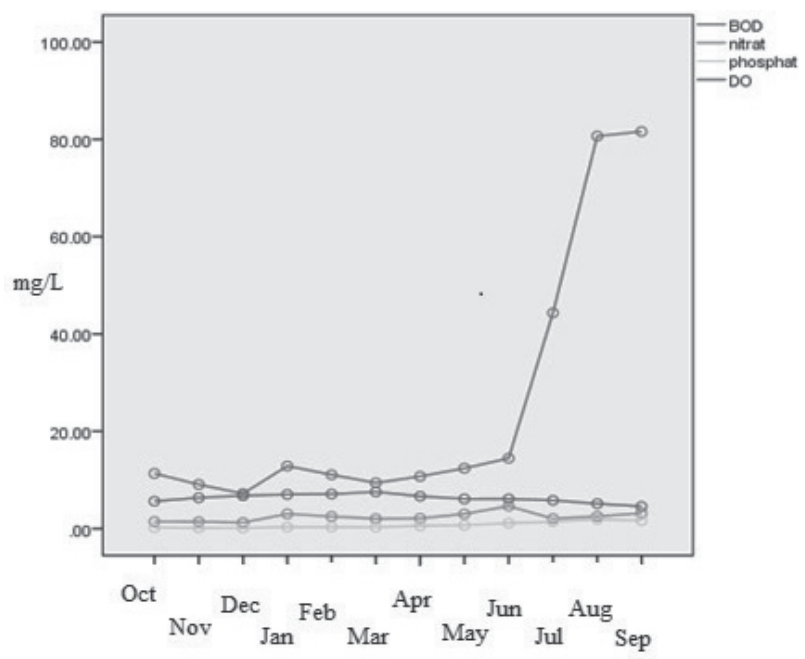

Fig. 2. The changing trends of nitrate, phosphate, DO, and BOD in different months of sampling. quality of water behind a large reservoir in Brazil [28]. They concluded that these techniques are very effective in reducing the number and frequency of samplings and this can lead to considerable savings in the cost of tests. In similar research on the Tigris River by Ismail et al. (2014), the role of multivariate statistical methods was evaluated to be quite positive in the design of an optimal monitoring network [29]. Likewise, Mohamed et al. (2015) used these methods to optimize a water quality monitoring network in the basin of the Klang River and were very satisfied with the obtained results [30]. Guigues et al. (2013) integrated ANOVA and multivariate statistical methods to redesign a water quality monitoring network [31]. They concluded that this technique was very applicable in understanding the complex nature of water quality issues and determining the priorities to improve water quality.

\section{Conclusions}

Generally, the findings of this study confirmed the applicability of multivariate techniques in determining the temporal frequency of measurements during the monitoring period. Determining the temporal frequency of water quality variables is the most important step in the design and operation of an optimal water quality monitoring network. Although continuous measurement of water quality parameters throughout the year seems necessary in some cases, it is not cost-effective. Therefore, the variables should be categorized temporally and limited to specific time periods in a way to demonstrate the reality of all changes in the quantity of water.

As discussed in this research, multivariate statistical techniques are one of the best ways to classify water quality parameters and determine the relative significance of the measurement periods and temporal frequency of monitoring.

These methods, taking into account the relationship between variables, can be beneficial in positioning the measurement stations and identifying the main water quality parameters to show the changes in the entire system under study. This will play a significant role in saving the time and cost of measurements. In other words, designing a water quality monitoring network with good performance is one of the most important issues in determining the quality of river water in a way that the measured parameters can indicate the whole changes in the water quality of the system to the extent possible. Identifying the stations of higher priority and main measurement parameters can be effective in making future decisions to optimize an existing water monitoring network, adding or excluding the measurement stations and new parameters, and updating the frequency of sampling.

TSS, BOD, and the remnants of medicines and chemicals are the three main sources of pollution contaminating the effluent from fish farms. These can be originated from different sources such as unused food, feces, urine, debris, and medicines (fungicides, malachite green, and antibiotics). Special attention 
should be paid on appropriate management practices to control the entry of the three types of pollutants to the receiving water resources. In this regard, issuing any license by relevant authorities for the establishment of fish farms must be subjected to compliance with all the environmental requirements. Accordingly, by principled aquaculture, environmental effects caused by the industry will be avoided in the future. In this respect, the following recommendations would be helpful:

- Accurate control and supervision by the organizations responsible for monitoring programs on strict enforcement of laws and discharge standards.

- Integrated soil and water management in the basin by the organizations responsible for the monitoring program.

- Study of suitable methods for managing, reducing, and controlling the effluent in accordance with a region's situation.

- Preventing the discharge of wastewater into the river and construction of wastewater treatment systems for urban (Amol and Gazanak cities) and rural population centers.

- Establishing an online monitoring network at the hydrometric stations.

- Pre-treating hot mineral waters on the fish farms.

- Monitoring and controlling chemical fertilizers and poisons consumed by farmers by encouraging them to produce organic products for the purpose of preventing contamination of surface and underground water resources caused by agricultural drainage.

\section{Acknowledgements}

We greatly appreciate the cordial cooperation of the Environmental Administration of Mazandaran Province in the implementation of this study.

\section{References}

1. Standard Methods for the Examination of Water and Wastewater. 21 $1^{\text {th }}$ edn, American Public Health Association/ American Water Works Association/Water Environment Federation, Washington DC, USA. 2005.

2. AUTHMAN M.M.N., ABBAS W.T., GAAFAR A.Y. Metals concentrations in Nile tilapia Oreochromis niloticus (Linnaeus, 1758) from illegal fish farm in Al-Minufiya Province, Egypt, and their effects on some tissues structures. Ecotoxicology and Environmental Safety, 84, 163, 2012.

3. MARTINEZ-GARCIA E., SANCHEZ-JEREZ P., AGUADO-GIMÉNEZ F., ÁVILA P., GUERRERO A., SÁNCHEZ-LIZASO J.L., FERNANDEZ-GONZALEZ V., GONZÁLEZ N., IGNASI GAIRIN J., CARBALLEIRA C., GARCÍA-GARCÍA B., CARRERAS J., CARLOS MACÍAS J., CARBALLEIRA A., COLLADO C. A metaanalysis approach to the effects of fish farming on soft bottom olychaeta assemblages in temperate regions. Marine Pollution Bulletin, 69 (1-2), 165, 2013.

4. KALANTZI I., SHIMMIELD T.M., PERGANTIS S.A., PAPAGEORGIOU N., BLACK K.D., KARAKASSIS I.
Heavy metals, trace elements and sediment geochemistry at four Mediterranean fish farms. Science of the Total Environment, 444, 128-137, 2013.

5. RABASSÓ M., HERNÁNDEZ J.M. Bioeconomic analysis of the environmental impact of a marine fish farm. Journal of Environmental Management, 158, 24, 2015.

6. ESMAEILI SARI A. The principles of water qualitative management in aquaculture, Iranian fisheries research Institute, 2000.

7. DOS SANTOS ROSA R., CAROLINA FORNERO AGUIAR A., GONÇALVES BOËCHAT I., GÜCKER B. Impacts of fish farm pollution on ecosystem structure and function of tropical headwater streams. Environmental POLLUTION, 174, 204, 2013.

8. CARTIER L.E., CARPENTER K.E. The influence of pearl oyster farming on reef fish abundance and diversity in Ahe, French Polynesia. Marine Pollution Bulletin, 78 (1-2), 43, 2014.

9. HERATH S.S., SATOH S. 15-Environmental impact of phosphorus and nitrogen from aquaculture. Feed and Feeding Practices in Aquaculture, 369, 2015.

10. JIANG ZH., LIAO Y., LIU J., SHOU L., CHEN Q., YAN X., ZHU G., ZENG J. Effects of fish farming on phytoplankton community under the thermal stress caused by a power plant in a eutrophic, semi-enclosed bay: Induce toxic dinoflagellate (Prorocentrum minimum) blooms in cold seasons. Marine Pollution Bulletin, 76 (1-2), 315, 2013.

11. Iranian Fisheries Corporation. The report on the hydrology of Haraz River, the faculty of natural resources and marine sciences, Tarbiat Modares University, 75, 2005.

12. HARNISZ M., KORZENIEWSKA E., GOŁAŚ I. The impact of a freshwater fish farm on the community of tetracycline-resistant bacteria and the structure of tetracycline resistance genes in river water. Chemosphere, 128, 134-141, 2015.

13. JAN R.Q., KAO SH.J., DAI CH.F., HO Ch.T. Assessment of the effects of cage fish-farming on damselfish-associated food chains using stable-isotope analyses. Marine Pollution Bulletin, 86 (1-2), 111, 2014.

14. THI ANH P., KROEZE C., BUSH S.R., MOL A.P.J. Water pollution by intensive brackish shrimp farming in south-east Vietnam: Causes and options for control. Agricultural Water Management, 97 (6), 872, 2010.

15. PINE H.J., BOYD C.E. Stream Salinization by Inland Brackish-Water Aquaculture. Journal: North American Journal of Aquaculture, 73 (2), 107, 2011.

16. SAREMI A., SAREMI K., SAREMI A., SADEGHI M., SEDGHI $\mathrm{H}$. The effect of aquaculture effluents on water quality parameters of Haraz River. Iranian Journal of Fisheries Sciences, 12 (2), 445, 2013.

17. MOHSENI-BANDPEI A., YOUSEFI Z. Status of Water Quality Parameters along Haraz River. International Journal of Environmental Research, 7 (4), 1029, 2013.

18. RUIZ-ZARZUELA I.L., HALAIHEL N, BALCÁZAR J.L., ORTEGA C., VENDRELL D., PÉREZ T., ALONSO J.L., DE BLAS I. Effect of fish farming on the water quality of rivers in northeast Spain. Water Science and Technology, 60 (3), 663, 2009.

19. VAREDI S.E., NASROLLAHZADEH H.S., FARABI S.M.V., VAHEDI F. Characterization and Impact of Rainbow Trout Farm Effluent on Water Quality of Haraz River. $8^{\text {th }}$ International River Engineering Conference, Ahwaz, Iran, 2009.

20. MAHBOOBI SOOFIANI N., HATAMI R., HEMAMI M. R., EBRAHIMI E. Effects of Trout Farm Effluent on Water Quality and the Macrobenthic Invertebrate Community of 
the Zayandeh-Roud River, Iran. North American Journal of Aquaculture, 74 (2), 132, 2012.

21. Iranian Statistics Center. General census of population and housing. Detailed results of Amol City, Iranian Statistics Center Publications, 2007.

22. AFSHINNEZHAD Y. Iran's Rivers, Second volume; Ministry of Energy Publications - Jamab Engineering Advisory Company. Iranian Fisheries Journal, 2, 28, 1994.

23. ROSHAN TABARI M. Hydrology and hydrobiology of Haraz River.Iranian Journal of Fish, 2, 28, 1995 [In Persian].

24. KARAMOUZ M., KARACHIAN R. Quality management of water resources. Amirkabir University of Technology Publications, Tehran, Iran, 256, 2003.

25. RACZYŃSKA M., MACHULA S., CHOIŃSKI A., SOBKOWIAK L. Influence of the fish pond aquaculture effluent discharge on abiotic environmental factors of selected rivers in Northwest Poland. Acta Ecologica Sinica, 32 (3), 160, 2012.

26. FARMAKI E.G., THOMAIDIS N.S., PASIAS I.N., BAULARD C., PAPAHARISIS L., EFSTATHIOU C.E. Environmental impact of intensive aquaculture: Investigation on the accumulation of metals and nutrients in marine sediments of Greece. Science of The Total Environment, 485, 554, 2015

27. LEÓN-MUÑOZ J., ECHEVERRÍA C., MARCÉ R., RISS
W., SHERMAN B., LUIS IRIARTE J. The combined impact of land use change and aquaculture on sediment and water quality in oligotrophic Lake Rupanco (North Patagonia, Chile, $40.8^{\circ} \mathrm{S}$ ). Journal of Environmental Management, 128, 283, 2013.

28. LOPES F.B., DE ANDRADE E.M., MEIRELES A.C.M., BECKER H., BATISTA A.A. Assessment of the water quality in a large reservoir in semiarid region of Brazil. Revista Brasileira de Engenharia Agrícola e Ambiental, 18 (4), 437, 2014.

29. ISMAIL A.H., ABED B.SH., ABDUL SH. Application of Multivariate Statistical Techniques in the surface water quality Assessment of Tigris River at Baghdad stretch, Iraq. Journal of Babylon University/Engineering Sciences, 22 (2), 450, 2014.

30. MOHAMED I., OTHMAN F., IBRAHIM A.I., ALAAELDIN M.E., YUNUS R.M. Assessment of water quality parameters using multivariate analysis for Klang River basin, Malaysia. Environmental Monitorring and AssessMent, 187 (1), 4182, 2015. Doi: 10.1007/s10661-0144182-y

31. GUIGUES N., DESENFANT M., HANCE E. Combining multivariate statistics and analysis of variance to redesign a water quality monitoring network. Environmental Science: Processes \& Impacts, 15, 1692, 2013. 